\title{
Serum sclerostin levels in Paget's disease and prostate cancer with bone metastases with a wide range of bone turnover ${ }^{\text {ts }}$
}

\author{
Maria P. Yavropoulou ${ }^{\mathrm{a}, 1}$, Antoon H. van Lierop ${ }^{\mathrm{a}, 1}$, Neveen A.T. Hamdy ${ }^{\mathrm{a}}$, \\ Rene Rizzoli ${ }^{\text {b }}$, Socrates E. Papapoulos ${ }^{\text {a,* }}$ \\ a Department of Endocrinology \& Metabolic Diseases Leiden University Medical Center, Leiden, The Netherlands \\ b Division of Bone Diseases, Geneva University Hospitals and Faculty of Medicine, Geneva Switzerland
}

\section{A R T I C L E I N F O}

\section{Article history:}

Received 14 December 2011

Revised 9 April 2012

Accepted 18 April 2012

Available online 2 May 2012

Edited by: R. Baron

\section{Keywords:}

sclerostin

Paget's disease

prostate cancer

bone formation

bone resorption

\begin{abstract}
A B S T R A C T
Evidence has been accumulating for the role of osteocytes as key players in the regulation of bone remodeling. One of the main products of these cells, sclerostin, inhibits bone formation and may also stimulate bone resorption. Circulating sclerostin has been evaluated in humans, but data are scarce in patients with different rates of bone turnover. To address this issue we evaluated serum sclerostin levels in patients with Paget's disease of bone (PD) and in patients with prostate cancer metastatic to the skeleton (PC)

Sclerostin levels were measured in 88 patients with PD, 20 patients with PC and 237 healthy individuals (113 men and 124 women, aged 20 to 77 years). Bone turnover was evaluated by measuring serum levels of procollagen type 1 amino-terminal propeptide (P1NP) in all individuals studied and $\beta$-carboxy-terminal cross-linking telopeptide of type I collagen ( $\beta$-CTX) only in patients. Patients were aged between 45 and 88 years and had a wide range of bone turnover: serum P1NP 9.2 to $1872 \mathrm{ng} / \mathrm{ml}$ and $\beta-C T X 50$ to $3120 \mathrm{pg} /$ ml. Patients with PD and with PC had significantly higher mean serum sclerostin levels $(53.1 \pm 22.7 \mathrm{pg} / \mathrm{ml}$ and $56.6 \pm 25.8 \mathrm{pg} / \mathrm{ml}$, respectively) compared to healthy controls $(38.1 \pm 12.1 \mathrm{pg} / \mathrm{ml})(\mathrm{p}<0.001)$. Serum sclerostin levels were significantly correlated with P1NP in all $(n=345)$ studied subjects $(r=0.32$, $\mathrm{p}<0.001)$. Circulating sclerostin levels are significantly increased in patients with increased bone turnover, regardless of underlying pathology. These increased levels may be due to a compensatory response to the increased number of osteoblasts at affected skeletal sites and may contribute to the increased bone resorption in patients with $\mathrm{PC}$.
\end{abstract}

(c) 2012 Elsevier Inc. All rights reserved.

\section{Introduction}

Osteocytes are former osteoblasts embedded in lacunae of the mineralized bone matrix. Over the last decade evidence has unfolded about the critical role of these abundant bone cells as orchestrators of bone remodeling through regulation of both osteoblast and osteoclast activity, and as endocrine regulators of phosphate homeostasis [1]. Osteocytes communicate with each other and with other cellular components of bone through an extensive network of cytoplasmic processes, thereby fine tuning the differentiation and function of these cells.

\footnotetext{
is Disclosures: All authors have no conflict of interest; Funding: European Commission-FP7 (TALOS:Health-F2-2008-201099).

* Corresponding author at: Dept of Endocrinology \& Metabolic Diseases, Leiden University Medical Center, Albinusdreef 2, 2333 ZA Leiden, The Netherlands. Fax: + 3171 5248136.

E-mail addresses: margia@med.auth.gr (M.P. Yavropoulou), a.h.j.m.van_lierop@lumc.nl (A.H. van Lierop),n.a.t.hamdy@lumc.nl (N.A.T. Hamdy), Rene.Rizzoli@unige.ch (R. Rizzoli), m.v.iken@lumc.nl (S.E. Papapoulos).

1 The first two authors contributed equally to this study.
}

One of the main secreted products of osteocytes, sclerostin, is solely expressed by mature cells and is considered a major negative local regulator of bone formation [2,3] . This takes place primarily through binding with the low-density lipoprotein receptor-related protein 5 and 6 (LRP5/6) co-receptors and consequently inhibiting the canonical Wnt signaling pathway [4,5]. Sclerostin has attracted much attention over the last few years due to its implication in the pathogenesis of two rare skeletal disorders characterized by substantial increase in bone mass, sclerosteosis and van Buchem disease [6-9]. In addition, suppression of sclerostin production is, at least partly, responsible for the anabolic effect of mechanical loading and PTH on bone [10-12].

Apart for its well documented role as an inhibitor of bone formation, sclerostin is also involved in the regulation of bone resorption. Recent evidence indicates that osteocytes are the main source of RANKL in the skeleton $[13,14]$ and that sclerostin promotes osteoclast formation and activity by osteocytes in a RANKL-dependent manner [15]. Moreover, a neutralizing antibody against sclerostin increased significantly the rate of bone formation in animal models while it did not change or decreased bone resorption, assessed 
histomorphometrically $[16,17]$. Finally, in a phase 1 clinical trial a single parenteral administration of an antibody to sclerostin led to a rapid and dose-dependent increase in serum P1NP and decreased serum CTX [18].

To obtain more insight into the relationships between sclerostin and bone remodeling in humans, we evaluated serum sclerostin levels in patients with Paget's disease of bone, characterized by predominantly increased bone resorption, at different stages of disease activity, and in patients with prostate cancer metastatic to the skeleton mainly characterized by increased bone formation, at different degrees of skeletal involvement.

\section{Material and Methods}

\section{Study population}

Eighty eight patients with biochemical, radiological and scintigraphic evidence for Paget's disease of bone and 20 patients with histological and scintigraphic evidence for prostate cancer metastatic to the skeleton, who were under regular control in the Outpatient Clinic of the Department of Endocrinology and Metabolic Diseases of the Leiden University Medical Center were included in the study. Exclusion criteria were impaired renal function (serum creatinine $>120 \mu \mathrm{mol} / \mathrm{l}$ ), impaired liver function, or the presence of diseases known to increase bone turnover other than Paget's disease of bone and prostate cancer. Stored at $-80^{\circ} \mathrm{C}$ and previously unthawed serum samples were measured for sclerostin, the bone formation marker procollagen type 1 amino-terminal propeptide (P1NP) and the bone resorption marker $\beta$-carboxy-terminal cross-linking telopeptide of type I collagen $(\beta-\mathrm{CTX})$.

\section{Subject characteristics}

Of the 88 patients with Paget's disease of bone, 47 had monostotic (predominantly pelvis) and 41 had polyostostic disease (ranging from 2 to 8 affected skeletal sites). Twenty four patients were treatment-naïve at the time of sampling and 64 had been previously treated with one or more (median 2) courses of bisphosphonates [short courses of intravenous pamidronate (45), olpadronate (46), EB-1053 (4) and zoledronate (1); monthly courses of oral olpadronate (3), oral etidronate (8) ]. Twenty eight of these patients had received treatment within the last 4 years, and 36 received their last course of treatment more than 5 years before the time of sampling (range 5 to 25 years). All patients with metastatic prostate cancer were androgen-deprived and bisphosphonate-treatment naïve at time of sampling.

Serum sclerostin levels obtained from patients were compared with those obtained from two cohorts of healthy individuals, who were used as controls. The first, previously described, cohort consisted of 72 healthy volunteers, 29 males and 43 females, with a mean age of 50.4 years (range: $20-77$ years) [19] . The second cohort consisted of 165 healthy individuals, 84 males and 81 females, with a mean age of 65.1 years (range 63-68 years) studied in collaboration with the Division of Bone Diseases of the University of Geneva [20]. All subjects had normal renal function and serum P1NP values below $65 \mathrm{ng} / \mathrm{ml}$.

The study was approved by the Medical Ethics Committees of the Leiden University Medical Center and the Geneva University Hospitals and informed consent was obtained from all participants.

\section{Biochemical assays}

Serum calcium, phosphate and creatinine were measured by semiautomated techniques. Serum alkaline phosphatase activity (ALP) was measured using a fully automated P800 modulator system (Roche BV) and 25-hydroxyvitamin D (25-OHD) by the Liason 25-
OHD assay (DiaSorin SA). Plasma PTH was measured by Immulite 2500 (Siemens Diagnostics). Serum P1NP and $\beta$-CTX were determined using the E-170 system (Roche BV).

\section{Sclerostin assay}

Sclerostin was measured in serum by an electrochemiluminescence assay (MSD 96-well MULTI-ARRAY Human Sclerostin Assay, Gaithersburg, MD, USA), as previously described [21]. In brief, the sclerostin standard for the assay was produced in an NSO-derived myeloma cell line, and was checked for purity by SDS-PAGE gel with silver stain. The intra- and inter-assay coefficients of variation were $6 \%$ and $10 \%$ respectively. The detection limit of the assay was $1 \mathrm{pg} / \mathrm{ml}$, and the detection range was $1-10,000 \mathrm{pg} / \mathrm{ml}$. Using this assay, sclerostin was detected in the serum of all healthy subjects and was undetectable in the serum of 19 patients with sclerosteosis [21].

\section{Statistical analysis}

Data are expressed as mean \pm Standard Deviation (SD). Normality of distribution was assessed by Kolmogorov-Smirnov test and logtransformation of data was applied for non-normally distributed variables. Student's t-test for independent samples or One-way ANOVA was used for differences between groups, as applicable. Pearson's $x^{2}$ test was applied to explore associations between sclerostin values and bone markers in serum. A probability level of random difference of 0.05 was considered significant. Data were analyzed using SPSS 16.0 (SPSS Inc., Chicago, IL, USA).

\section{Results}

The patient population studied consisted of 108 subjects ( 75 men and 33 women) with a mean age of 68.1 years (range 45 to 88 years). Demographic characteristics and laboratory values are shown in Table 1 . As intended by study design, there was a wide range of bone turnover within the patient population, with serum P1NP ranging from 9.2 to $1872 \mathrm{ng} / \mathrm{ml}$ (mean $223.3 \mathrm{ng} / \mathrm{ml}$ ) and $\beta$-CTX ranging from 50 to $3120 \mathrm{pg} / \mathrm{ml}$ (mean $642.0 \mathrm{pg} / \mathrm{ml}$ ) (Fig. 1). There was a significant correlation between serum levels of $\beta$-CTX and P1NP in the whole patient population studied $(r=0.78, p<0.001)$, as well in the two separate patient groups (Paget's disease of bone: $\mathrm{r}=0.69, \mathrm{p}=<0.001$, bone metastatic disease: $\mathrm{r}=0.86, \mathrm{p}<0.001$ ).

\section{Circulating sclerostin levels}

In patients, mean serum sclerostin level was $53.8 \mathrm{pg} / \mathrm{ml}$ (range $11.9 \mathrm{pg} / \mathrm{ml}$ to $135.2 \mathrm{pg} / \mathrm{ml})$ and was significantly higher $(\mathrm{p}<0.001)$ than the mean value of sclerostin of all 237 healthy controls ( $38.1 \mathrm{pg} / \mathrm{ml}$; range $12.4 \mathrm{pg} / \mathrm{ml}$ to $80.1 \mathrm{pg} / \mathrm{ml}$ ) (Fig. 2). In both patients

Table 1

Demographic characteristics and baseline laboratory values of patients and controls.

\begin{tabular}{|c|c|c|c|c|}
\hline \multirow[b]{2}{*}{ Number } & \multirow{2}{*}{$\begin{array}{l}\text { Paget's disease } \\
\text { of bone } \\
88\end{array}$} & \multirow{2}{*}{$\begin{array}{l}\begin{array}{l}\text { Metastatic } \\
\text { prostate cancer }\end{array} \\
20\end{array}$} & \multirow{2}{*}{$\begin{array}{l}\text { Controls } \\
237\end{array}$} & \multirow{2}{*}{$\begin{array}{l}\text { Reference } \\
\text { range } \\
-\end{array}$} \\
\hline & & & & \\
\hline Male : female & $55: 33$ & $20: 0$ & $113: 124$ & - \\
\hline Age (yrs) & $67.4 \pm 10.6$ & $71.1 \pm 7.3$ & $60 \pm 11.3$ & - \\
\hline BMI $\left(\mathrm{kg} / \mathrm{cm}^{2}\right)$ & $27.6 \pm 4.1$ & $26.4 \pm 3.7$ & $25.1 \pm 4.3$ & - \\
\hline P1NP (ng/ml) & $158 \pm 235$ & $511 \pm 441$ & $35.6 \pm 12.7$ & $<65$ \\
\hline $\operatorname{ALP}(\mathrm{U} / \mathrm{l})$ & $196 \pm 248$ & $834 \pm 900$ & $65.3 \pm 16.3^{1}$ & $40-120$ \\
\hline$\beta-C T X(p g / m l)$ & $498 \pm 330$ & $1,275 \pm 806$ & - & $<590$ \\
\hline Calcium $(\mathrm{mmol} / \mathrm{l})$ & $2.37 \pm 0.14$ & $2.26 \pm 0.12$ & $2.27 \pm 0.08^{1}$ & $2.15-2.55$ \\
\hline Phosphate (mmol/l) & $1.05 \pm 0.17$ & $1.09 \pm 0.27$ & $1.07 \pm 0.15^{1}$ & $0.90-1.50$ \\
\hline Creatinine $(\mu \mathrm{mol} / \mathrm{l})$ & $88.4 \pm 13.5$ & $81.2 \pm 16.6$ & $77 \pm 15$ & $44-120$ \\
\hline $25-\mathrm{OHD}(\mathrm{nmol} / \mathrm{l})$ & $58.6 \pm 28.6$ & $55.3 \pm 24.9$ & - & $>50$ \\
\hline PTH (pmol/l) & $6.6 \pm 3.6$ & $5.0 \pm 1.6$ & - & $1.5-8.0$ \\
\hline
\end{tabular}

1 Values obtained in a subset of the cohort (LUMC). 


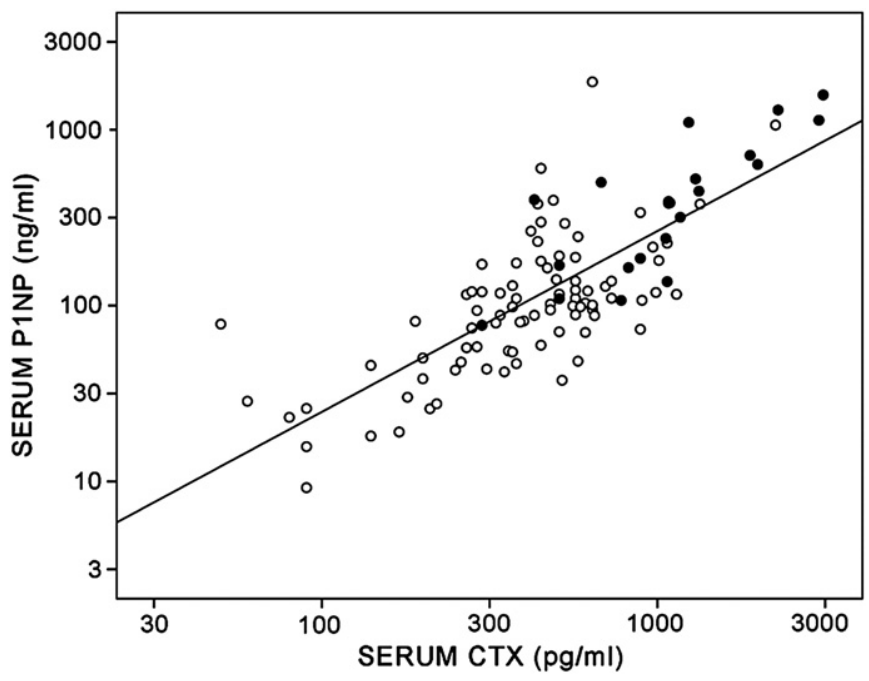

Fig. 1. Serum levels of P1NP and CTX in patients with Paget's disease of bone, and prostate cancer with bone metastasis. Open circles Paget's disease of bone, closed circles bone metastatic disease from prostate cancer. $(r=0.78, \mathrm{p}<0.001)$.

and healthy individuals there was no correlation between serum sclerostin levels and age.

Paget's disease of bone

In patients with Paget's disease sclerostin levels ranged from 11.9 to $135.2 \mathrm{pg} / \mathrm{ml}$, with the mean level being significantly higher than that of healthy controls $(53.1 \mathrm{pg} / \mathrm{ml}$ vs $38.1 \mathrm{pg} / \mathrm{ml}$ respectively, $\mathrm{p}<0.001)$. Because of the predominance of elderly men in the Paget's cohort, results were also analyzed according to gender and age (younger or older than 65 years). Results showed that the difference in sclerostin values remained robust (Table 2). There was no significant difference in mean levels of sclerostin between previously bisphosphonate-treated and bisphosphonate-treatment naïve patients ( $55.2 \mathrm{pg} / \mathrm{ml}$ vs. $47.5 \mathrm{pg} / \mathrm{ml}$ respectively, $\mathrm{p}=0.16$ ), while these were higher in patients with polyostotic compared to monostotic disease (59.0 pg/ml vs. $48.1 \mathrm{pg} / \mathrm{ml}, \mathrm{p}=0.024)$.

Prostate cancer metastatic to the skeleton

In patients with prostate cancer metastatic to the skeleton serum sclerostin levels ranged from $19.4 \mathrm{pg} / \mathrm{ml}$ to $120.5 \mathrm{pg} / \mathrm{ml}$, with a mean level significantly higher than that of healthy controls (56.6 vs.

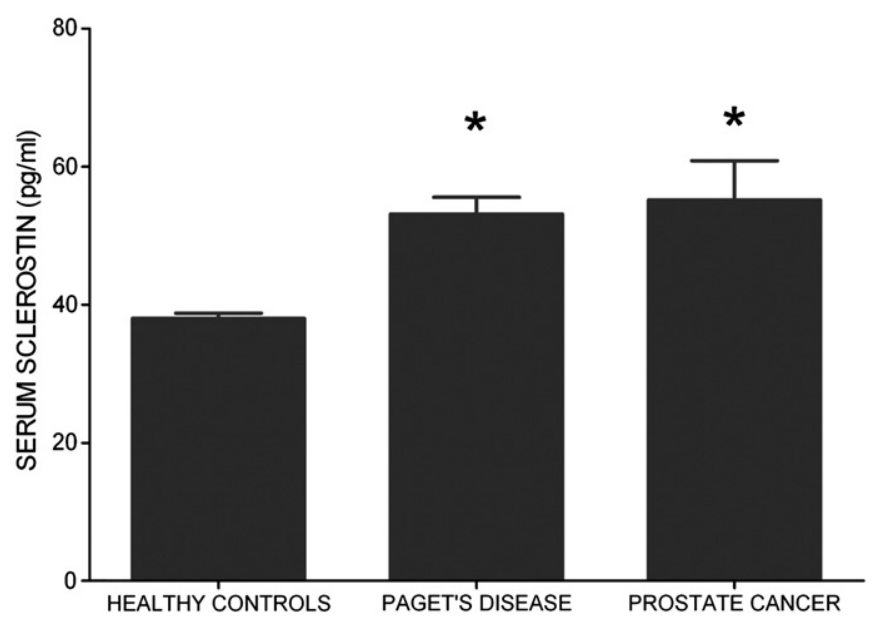

Fig. 2. Serum sclerostin levels in healthy subjects, and patients with Paget's disease of bone, and prostate cancer with bone metastasis. ${ }^{*}: \mathrm{p}<0.01$.
Table 2

Serum sclerostin in healthy individuals and patients with Paget's disease and prostate cancer matastatic to bone.

\begin{tabular}{lllll}
\hline Subjects & all & $>65$ years & men & men $>65$ years \\
\hline Healthy & $38.1 \pm 12.1$ & $38.3 \pm 9.9$ & $40.2 \pm 12.5$ & $39.8 \pm 10.2$ \\
& $(\mathrm{n}=237)$ & $(\mathrm{n}=102)$ & $(\mathrm{n}=113)$ & $(\mathrm{n}=55)$ \\
Paget's disease & $53.1 \pm 22.7^{*}$ & $53.5 \pm 25.3^{*}$ & $55.4 \pm 24.1^{*}$ & $\begin{array}{l}55.8 \pm 27.6^{* *} \\
(\mathrm{n}=33)\end{array}$ \\
$\begin{array}{l}\text { Prostate cancer } \\
\text { N }=88)\end{array}$ & $\begin{array}{l}\mathrm{5}=5.6 \pm 25.8^{* *} \\
(\mathrm{n}=20)\end{array}$ & $\begin{array}{l}54.9 \pm 22.8^{* *} \\
(\mathrm{n}=16)\end{array}$ & $\begin{array}{l}56.6 \pm 25.8^{* *} \\
(\mathrm{n}=20)\end{array}$ & $\begin{array}{l}54.9 \pm 22.8^{* * *} \\
(\mathrm{n}=16)\end{array}$ \\
\hline
\end{tabular}

${ }^{*} \mathrm{p}<0.001{ }^{* *} \mathrm{p}<0.01{ }^{* * *} \mathrm{p}=0.019$, compared to healthy subjects.

$38.1 \mathrm{pg} / \mathrm{ml}$, respectively, $\mathrm{p}=0.005)$. This difference remained significant when values of patients were compared to those of healthy males or healthy males older than 65 years (Table 2 ). There was no difference in mean sclerostin levels between patients with prostate cancer metastatic to the skeleton and those with Paget's disease of bone $(\mathrm{p}=0.55)$.

\section{Relationship between sclerostin levels and biochemical markers of bone turnover}

There was a significant relationship between serum sclerostin and serum P1NP in all studied subjects $(n=345, r=0.32, p<0.001)$. In patients with Paget's disease alone, there was no relationship between serum sclerostin and P1NP levels $(r=0.08, p=0.45)$ In contrast, in patients with prostate cancer serum levels of sclerostin were significantly correlated with those of P1NP $(r=0.56, . p=0.01)$ (Fig. 3). Circulating sclerostin levels were not correlated with levels of $\beta$-CTX in the whole patient population $(r=0.16, p=0.09)$, or in patients with Paget's disease $(r=0.08, p=0.46)$, but were correlated in patients with prostate cancer $(r=0.48, p=0.03)$ (Fig. 3 ).

\section{Discussion}

Sclerostin is an osteocyte-produced local regulator of bone remodeling affecting both osteoblast and osteoclast function $[2,3,15]$. A previous study has shown that there is a strong relationship between circulating and bone marrow plasma levels of sclerostin consistent with the findings that osteocytes are the major source of sclerostin production and, therefore, the sclerostin present in peripheral blood [22]. Our data show that circulating levels of sclerostin are significantly increased in diseases associated with increased bone turnover, such as Paget's disease and prostate cancer metastatic to the skeleton, regardless of the underlying pathogenetic mechanism responsible for the increased bone turnover.

In Paget's disease of bone, bone resorption is increased and is followed by increased and disorganized bone formation. In prostate cancer, skeletal metastases are mainly osteoblastic but increased bone resorption has also been biochemically, as also shown here, and histologically documented [23-27]. Despite the difference in the pathogenetic mechanisms of Paget's disease of bone and prostate cancer metastatic to the skeleton, both disorders share the common end-result of increased bone turnover. We found increased circulating sclerostin levels in both diseases compared to healthy controls which were independent of renal function, age and previous bisphosphonate treatment. All subjects included in our study had normal renal function and it was recently shown that serum sclerostin levels increase sharply in subjects with renal impairment (CKD 3 stage) [28]. We did not find any association of serum sclerostin levels with age consistent with some [29-33] but not other [28,34-38] reports which may reflect differences in the characteristics of studied cohorts and specificity of sclerostin assays. Finally, previous bisphosphonate treatment of patients with Paget's disease had no effect on sclerostin levels which may be due to inability of used bisphosphonates to reach the osteocytes and/or the 
A

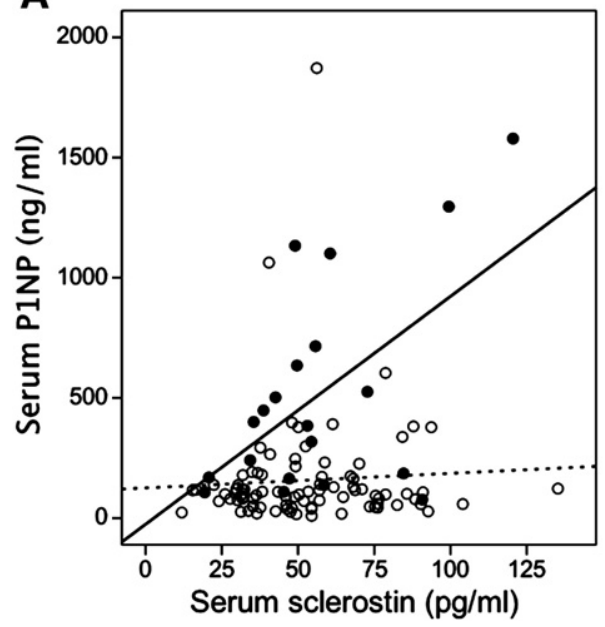

B

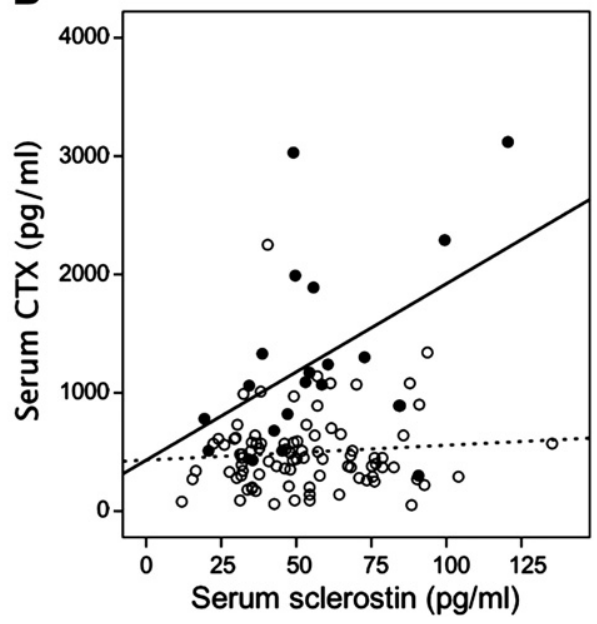

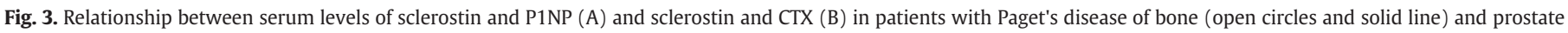
cancer with bone metastasis (closed circles and interrupted line).

long intervals following the short exposure to these agents in our study. In previous studies of patients with osteoporosis serum sclerostin levels did not change during treatment with alendronate [32] while they increased during treatment with risedronate or neridronate given intramuscularly [30,39].

We found, in addition, a significant positive relationship between sclerostin levels and bone turnover markers in metastatic prostate cancer but not in Paget's disease of bone. Although this result may reflect the difference in underlying pathophysiology between the two disorders, it remains difficult to draw any conclusion about the exact mechanism which regulates sclerostin production in these conditions. We could speculate, however, that in both diseases osteocytes may secrete more sclerostin as a compensatory response to the increased number of osteoblasts that are recruited to the affected skeletal sites.

A number of factors could stimulate sclerostin production by osteocytes in either disorder. It has recently been demonstrated that, Dkk-1, an antagonist of Wnt signaling, is also significantly elevated in the serum of patients with Paget's disease of bone [40]. Dkk-1 expression and protein concentration have also been reported to be elevated in osteoblastic and stromal cell cultures from Pagetic lesions [41]. In addition, Dkk-1 has been found to positively regulate sclerostin expression and to enhance suppression of the Wnt signaling pathway in inflammatory-induced bone loss, so that an increased production of Dkk-1 by Pagetic lesions could also be responsible for increased sclerostin production by osteocytes [42]. Cytokines produced by prostate cancer cells, such as BMP-6 [43,44], which is a known stimulator of sclerostin production [45,46], could also contribute to the increased circulating levels of sclerostin observed in prostate cancer metastatic to the skeleton. This increased sclerostin production may in turn stimulate RANKL and bone resorption. Sclerostin was recently shown to upregulate the expression of RANKL by osteocyte-like cells and to promote osteoclastogenesis [15], supporting also the view that osteocytes are targets for sclerostin action. This sequence of events can explain the association between serum sclerostin levels with those of P1NP and CTX observed in patients with prostate cancer metastatic to the skeleton. The same mechanism may not be operational in Paget's disease in which RANKL is already upregulated [47].

In conclusion we demonstrate increased circulating sclerostin levels in two skeletal disorders characterized by increased bone turnover, regardless of their underlying pathogenetic mechanisms. These increases in serum sclerostin may be due to a compensatory response to the increased number of osteoblasts at affected skeletal sites and may contribute to increased bone resorption in patients with prostate cancer with bone metastases.

\section{Authors contributions}

MPY, AvL, NATH and SEP contributed to the conception, design, analysis and interpretation of data. NATH and SEP contributed to the acquisition of data. RR was responsible for the conception, acquisition and analysis of the data of the Geneva study. All authors participated in drafting and revising the manuscript and approved the final version of the manuscript. MPY and SP take responsibility for the integrity of the analysis of the data.

\section{Ackowledgements}

We are indebted to Claire Durosier PhD and Fanny Merminod RD for their help in enrollment of subjects and collection of data in Geneva.

\section{References}

[1] Bonewald LF. The amazing osteocyte. J Bone Miner Res 2011;26:229-38.

[2] van Bezooijen RL, Roelen BA, Visser A, van der Wee-Pals L, de Wilt E, Karperien M, et al. Sclerostin is an osteocyte-expressed negative regulator of bone formation, but not a classical BMP antagonist. J Exp Med 2004;199:805-14.

[3] Winkler DG, Sutherland MK, Geoghegan JC, Yu C, Hayes T, Skonier JE, et al. Osteocyte control of bone formation via sclerostin, a novel BMP antagonist. EMBO J 2003;22:6267-76.

[4] Li X, Zhang Y, Kang H, Liu W, Liu P, Zhang J, et al. Sclerostin binds to LRP5/6 and antagonizes canonical Wnt signaling. J Biol Chem 2005;280:19883-7.

[5] van Bezooijen RL, Svensson JP, Eefting D, Visser A, van der Horst G, Karperien M, et al. Wht but not BMP signaling is involved in the inhibitory action of sclerostin on BMP-stimulated bone formation. J Bone Miner Res 2007;22:19-28.

[6] Balemans W, Ebeling M, Patel N, Van HE, Olson P, Dioszegi M, et al. Increased bone density in sclerosteosis is due to the deficiency of a novel secreted protein (SOST). Hum Mol Genet 2001;10:537-43.

[7] Brunkow ME, Gardner JC, Van NJ, Paeper BW, Kovacevich BR, Proll S, et al. Bone dysplasia sclerosteosis results from loss of the SOST gene product, a novel cystine knot-containing protein. Am J Hum Genet 2001;68:577-89.

[8] Balemans W, Patel N, Ebeling M, Van HE, Wuyts W, Lacza C, et al. Identification of a $52 \mathrm{~kb}$ deletion downstream of the SOST gene in patients with van Buchem disease. J Med Genet 2002;39:91-7.

[9] Staehling-Hampton K, Proll S, Paeper BW, Zhao L, Charmley P, Brown A, et al. A $52-\mathrm{kb}$ deletion in the SOST-MEOX1 intergenic region on 17q12-q21 is associated with van Buchem disease in the Dutch population. Am J Med Genet 2002;110: 144-52.

[10] Lin C, Jiang X, Dai Z, Guo X, Weng T, Wang J, et al. Sclerostin mediates bone response to mechanical unloading through antagonizing Wnt/beta-catenin signaling. J Bone Miner Res 2009;24:1651-61.

[11] O'Brien CA, Plotkin LI, Galli C, Goellner JJ, Gortazar AR, Allen MR, et al. Control of bone mass and remodeling by PTH receptor signaling in osteocytes. PLoS One 2008;3:e2942. 
[12] Robling AG, Niziolek PJ, Baldridge LA, Condon KW, Allen MR, Alam I, et al. Mechanical stimulation of bone in vivo reduces osteocyte expression of Sost/sclerostin. J Biol Chem 2008;283:5866-75.

[13] Nakashima T, Hayashi M, Fukunaga T, Kurata K, Oh-Hora M, Feng JQ et al. Evidence for osteocyte regulation of bone homeostasis through RANKL expression. Nat Med 2011;17:1231-4.

[14] Xiong J, Onal M, Jilka RL, Weinstein RS, Manolagas SC, O'Brien CA. Matrixembedded cells control osteoclast formation. Nat Med 2011;17:1235-41.

[15] Wijenayaka AR, Kogawa M, Lim HP, Bonewald LF, Findlay DM, Atkins GJ. Sclerostin Stimulates Osteocyte Support of Osteoclast Activity by a RANKLDependent Pathway. PLoS One 2011;6:e25900.

[16] Li X, Ominsky MS, Warmington KS, Morony S, Gong J, Cao J, et al. Sclerostin antibody treatment increases bone formation, bone mass, and bone strength in a rat model of postmenopausal osteoporosis. J Bone Miner Res 2009;24:578-88.

[17] Ominsky MS, Vlasseros F, Jolette J, Smith SY, Stouch B, Doellgast G, et al. Two doses of sclerostin antibody in cynomolgus monkeys increases bone formation, bone mineral density, and bone strength. J Bone Miner Res 2010;25:948-59.

[18] Padhi D, Jang G, Stouch B, Fang L, Posvar E. Single-dose, placebo-controlled, randomized study of AMG 785, a sclerostin monoclonal antibody. J Bone Miner Res 2011;26:19-26.

[19] van Lierop AH, Witteveen JE, Hamdy NA, Papapoulos SE. Patients with primary hyperparathyroidism have lower circulating sclerostin levels than euparathyroid controls. Eur J Endocrinol 2010;163:833-7.

[20] Durosier C, van Lierop A, Ferrari S, Chevally T, Papapoulos S, Rizolli R. Circulating Sclerostin Correlates to Bone Mineral Mass, Micro-Structure and Turnover in Healthy Elderly Men and Women. J Bone Miner Res 2011;26(s1):S221.

[21] van Lierop AH, Hamdy NA, Hamersma H, van Bezooijen RL, Power J, Loveridge N, et al. Patients with sclerosteosis and disease carriers: human models of the effect of sclerostin on bone turnover. J Bone Miner Res 2011;26:2804-11.

[22] Drake MT, Srinivasan B, Modder UI, Peterson JM, McCready LK, Riggs BL, et al. Effects of parathyroid hormone treatment on circulating sclerostin levels in postmenopausal women. J Clin Endocrinol Metab 2010;95:5056-62.

[23] Charhon SA, Chapuy MC, Delvin EE, Valentin-Opran A, Edouard CM, Meunier PJ. Histomorphometric analysis of sclerotic bone metastases from prostatic carcinoma special reference to osteomalacia. Cancer 1983;51:918-24.

[24] Ikeda I, Miura T, Kondo I. Pyridinium cross-links as urinary markers of bone metastases in patients with prostate cancer. Br J Urol 1996;77:102-6.

[25] Pelger RC, Hamdy NA, Zwinderman AH, Nijeholt AA, Papapoulos SE. Effects of the bisphosphonate olpadronate in patients with carcinoma of the prostate metastatic to the skeleton. Bone 1998;22:403-8.

[26] Percival RC, Urwin GH, Harris S, Yates AJ, Williams JL, Beneton M, et al. Biochemical and histological evidence that carcinoma of the prostate is associated with increased bone resorption. Eur J Surg Oncol 1987;13:41-9.

[27] Urwin GH, Percival RC, Harris S, Beneton MN, Williams JL, Kanis JA. Generalised increase in bone resorption in carcinoma of the prostate. Br J Urol 1985;57:721-3.

[28] Kim S, Kim H, Yoon S, Lee C, Lim S, Rhe Y. Decreased Renal Function but not Live Function Overpowers the Circulating Sclerostin Level. J Bone Miner Res 2011;26(Suppl. 1):S357-8.

[29] Mirza FS, Padhi ID, Raisz LG, Lorenzo JA. Serum sclerostin levels negatively correlate with parathyroid hormone levels and free estrogen index in postmenopausal women. J Clin Endocrinol Metab 2010;95:1991-7.

[30] Polyzos SA, Anastasilakis AD, Bratengeier C, Woloszczuk W, Papatheodorou A, Terpos E. Serum sclerostin levels positively correlate with lumbar spinal bone mineral density in postmenopausal women-the six-month effect of risedronate and teriparatide. Osteoporos Int 2011 [epub ahead of print].

[31] Sheng Z, Tong D, Ou Y, Zhang H, Zhang Z, Li S, et al. Serum sclerostin levels were positively correlated with fat mass and bone mineral density in central south Chinese postmenopausal women. Clin Endocrinol 2011 [epub ahead of print].

[32] Chung YE, Lee SH, Lee SY, Kim SY, Kim HH, Mirza FS, et al. Long-term treatment with raloxifene, but not bisphosphonates, reduces circulating sclerostin levels in postmenopausal women. Osteoporos Int 2011 [epub ahead of print].

[33] Kaji H, Imanishi Y, Sugimoto T, Seino S. Comparisons of serum sclerostin levels among patients with postmenopausal osteoporosis, primary hyperparathyroidism and osteomalacia. Exp Clin Endocrinol Diabetes 2011;119:440-4.

[34] Morse LR, Sudhakar S, Danilack V, Tun C, Lazzari A, Gagnon DR, et al. Association between sclerostin and bone density in chronic SCI. J Bone Miner Res 2011 [epub ahead of print].

[35] Modder UI, Hoey KA, Amin S, McCready LK, Achenbach SJ, Riggs BL, et al. Relation of age, gender, and bone mass to circulating sclerostin levels in women and men.J Bone Miner Res 2011;26:373-9.

[36] Garcia-Martin A, Rozas-Moreno P, Reyes-Garcia R, Morales-Santana S, GarciaFontana B, Garcia-Salcedo JA, et al. Circulating Levels of Sclerostin Are Increased in Patients with Type 2 Diabetes Mellitus. J Clin Endocrinol Metab 2011;97: 234-41.

[37] Ardawi MS, Al-Kadi HA, Rouzi AA, Qari MH. Determinants of serum sclerostin in healthy pre- and postmenopausal women. J Bone Miner Res 2011;26:2812-22.

[38] Amrein K, Amrein S, Drexler C, Dimai HP, Dobnig H, Pfeifer K, et al. Sclerostin and its association with physical activity, age, gender, body composition, and bone mineral content in healthy adults. J Clin Endocrinol Metab 2012;97: 148-54.

[39] Gatti D, Viapiana O, Adami S, Idolazzi L, Fracassi E, Rossini M. Bisphosphonate treatment of postmenopausal osteoporosis is associated with a dose dependent increase in serum sclerostin. Bone 2011 [epub ahead of print].

[40] Marshall MJ, Evans SF, Sharp CA, Powell DE, McCarthy HS, Davie MW. Increased circulating Dickkopf-1 in Paget's disease of bone. Clin Biochem 2009;42:965-9.

[41] Naot D, Bava U, Matthews B, Callon KE, Gamble GD, Black M, et al. Differential gene expression in cultured osteoblasts and bone marrow stromal cells from patients with Paget's disease of bone. J Bone Miner Res 2007;22:298-309.

[42] Heiland GR, Zwerina K, Baum W, Kireva T, Distler JH, Grisanti M, et al. Neutralisation of Dkk-1 protects from systemic bone loss during inflammation and reduces sclerostin expression. Ann Rheum Dis 2010;69:2152-9.

[43] Barnes J, Anthony CT, Wall N, Steiner MS. Bone morphogenetic protein-6 expression in normal and malignant prostate. World J Urol 1995;13:337-43.

[44] Dai J, Keller J, Zhang J, Lu Y, Yao Z, Keller ET. Bone morphogenetic protein-6 promotes osteoblastic prostate cancer bone metastases through a dual mechanism. Cancer Res 2005;65:8274-85.

[45] Ohyama Y, Nifuji A, Maeda Y, Amagasa T, Noda M. Spaciotemporal association and bone morphogenetic protein regulation of sclerostin and osterix expression during embryonic osteogenesis. Endocrinology 2004;145:4685-92.

[46] Sutherland MK, Geoghegan JC, Yu C, Winkler DG, Latham JA. Unique regulation of SOST, the sclerosteosis gene, by BMPs and steroid hormones in human osteoblasts. Bone 2004;35:448-54.

[47] Menaa C, Reddy SV, Kurihara N, Maeda H, Anderson D, Cundy T, et al. Enhanced RANK ligand expression and responsivity of bone marrow cells in Paget's disease of bone. J Clin Invest 2000;105:1833-8. 